\title{
Limb Failure Indicator
}

National Cancer Institute

\section{Source}

National Cancer Institute. Limb Failure Indicator. NCI Thesaurus. Code C119554.

An indication as to whether limb failure occurred. 